\title{
Alterations in IGF-I affect elderly: role of physical activity
}

\author{
Sagiv Moran • Yamin Chen • Amir Ruthie • Yenon Nir
}

Received: 14 May 2007 / Accepted: 24 June 2007 / Published online: 5 September 2007

(C) EGREPA 2007

\begin{abstract}
The growth hormone-insulin-like growth factor I (IGF-I) axis is an important physiological regulator muscle for development. Although there is evidence that aging muscle retains the ability to synthesize IGF-I, there is also evidence that aging may be associated with attenuation of the ability of exercise to induce an isoform of IGF-I that promotes satellite cell proliferation. However, it is clear that overexpression of IGF-I in the muscle can protect against age-related sarcopenia. Strength training appears to be the intervention of choice for the prevention and treatment of sarcopenia. IGF-I has been implicated in the loss of the muscle with age, and IGF-I expression levels change as a consequence of strength training in older adults. However, it seems that advancing age, rather than declining serum levels of IGF-I, appears to be a major determinant of lifetime changes in body composition in women and men. We concluded that resistive exercise is a significant determinant of muscle mass and function. Elevated levels of IGF-I have been found in physically active compared to sedentary individuals. Recent work suggests that IGF-I as a mediator plays an important role in muscle hypertrophy and angiogenesis, both of which characterize the anabolic adaptation of muscles to exercise.
\end{abstract}

Keywords Aerobic exercise · Aging · Growth factors .

Resistive training $\cdot$ Sarcopenia

Human muscle strength declines at the rate of $12-14 \%$ per decade after the age of 50 years $[66,68]$. This loss of

\footnotetext{
S. Moran $(\varangle) \cdot$ Y. Chen $\cdot$ A. Ruthie $\cdot$ Y. Nir

Biogenetic Laboratory, The Zinman College of Physical

Education and Sport Sciences,

1515 Holcombe Blvd.,

Wingate 42902, Israel

e-mail: moransag@012.net.il
}

strength with age is due to many factors but is primarily attributed to a loss of muscle mass bringing to sarcopenia $[30,86]$. Sarcopenia is related to a loss of functional abilities [82], dependency [83], increased risk of falls, fractures [5, 67], and decreased bone mineral density [94]. Thus, sarcopenia has negative consequences for the health status and functional abilities of older adults. Recent research has addressed the hypothesis that growth hormone (GH) and insulin-like growth factor I (IGF-I) have an anabolic effect in adults, including the elderly. These hormones stimulate whole-body and muscle protein synthesis, at least under some conditions. Serum IGF-I levels as well as GH secretion decline with advancing age [26, 92, 93]. The declining activity of the GH-IGF-I axis with advancing age may contribute to the decrease in lean body mass and the increase in mass of adipose tissue that occur with aging [17, 44, 100].

Mechanisms underlying age-associated change in body composition such as an increase in body fat and a decrease in bone mass are not fully understood. Decrease in GH secretion and serum IGF-I levels with aging may have some impact on these processes. IGF-I is predominantly synthesized in the liver, and serum levels of IGF-I are tightly regulated by GH release [79] and are indicated to reflect the integrated 24-h secretion of GH [15]. IGF-I is a trophic factor required for the proliferation of myoblasts, the proliferation of myogenic differentiation, and subsequent growth and hypertrophy of myofibers [27]. IGF-I has been identified as a potent regulator of gene expression in the skeletal muscle. Excitation-contraction uncoupling has been identified as a mechanism underlying sarcopenia in the skeletal muscle in aging mammals. The basic mechanism for excitationcontraction uncoupling is a larger number of ryanodine receptors uncoupled to dihydropyridine receptors [17]. In addition to effects on muscle development, IGF-I facilitates 
skeletal muscle dihydropyridine activity via tyrosine kinaseprotein kinase C-dependent phosphorylation [18]. It has also shown that IGF-I-dependent dihydropyridine modulation is impaired in aging skeletal muscles [87], which may explain, at least partially, the decline in muscle force with aging [79]. It has been established that high levels of GH and IGF-I increase body weight, bolster bone and muscle mass, and enhance immune function [64]. These hormones also modulate the onset of puberty and generally increase reproductive fitness. Furthermore, administration of GH or IGF-I to aged animals restores many of the deficits associated with age, including declines in immune function, bone mass, and skin thickness [16]. In addition to the attenuation of age-related physical deficits, administration of IGF-I to rodents prevents the development of age-related cognitive impairments [71]. These findings and others not detailed in this review provide evidence that the deficiency in GH and IGF-I contributes to the aged phenotype.

As described earlier in this review, GH and IGF-I are potent anabolic hormones that increase cellular metabolism and as a result enhance the function of numerous tissues. This effect is particularly important during development, when GH and IGF-I levels are high, and during aging, when these hormones' levels are low. It was propose that the GH-IGF-I-induced increase in metabolic activity results in increased glucose utilization, increased oxygen consumption, and increased oxidative stress [69].

In middle and late adulthood, all people experience a series of progressive alterations in body composition [93]. The contraction in lean body mass reflects atrophic processes in the liver, kidney, spleen, skin, bone, and skeletal muscle because of slower muscle protein synthesis. These structural changes have been considered unavoidable results of aging. It has recently been proposed, however, that reduced availability of $\mathrm{GH}$ in late adulthood may contribute to such changes [74, 93]. This proposal is based on two lines of evidence. First, after about the age of 30, the secretion of GH by the pituitary gland tends to decline [25, $92,93]$. Second, GH secretion can be measured indirectly by measuring the plasma concentration of IGF-I (also known as somatomedin C), which is produced and released in response to $\mathrm{GH}$ [14]. Because GH is secreted in pulses, mostly during the early hours of sleep, it is difficult to measure the 24-h secretion of the substance directly. There is little diurnal variation in the plasma IGF-I concentration, and measurements of it are therefore a convenient indicator of $\mathrm{GH}$ secretion [14]. Therefore, the atrophy of the lean body mass, its component organs, and the enlargement mass of adipose tissue, which are characteristic of the elderly, result at least in part from diminished secretion of GH [74, 93]. If so, the agerelated changes in body composition may be correctable in part by the administration of human $\mathrm{GH}$, now readily available as a biosynthetic product [50].
In healthy individuals, the anabolic GH-IGF-I axis maintains muscle mass by suppressing protein degradation, increasing amino acid uptake, and stimulating protein synthesis [89]. The bioavailability of IGF-I is dependent upon circulating IGF-I and IGF-I-binding protein (IGFBP) levels (fibroblast growth factor [FGF] 2). Like IGF-I, FGF-2 is ubiquitously distributed and is one of the most potent mitogens for myoblasts and plays a critical role in myogenesis and capillary angiogenesis during muscle development [4]. Furthermore, stress-induced muscle remodeling and repair after extensive pathological injuries are believed to be activated by FGF-2. It is also suggested that low levels of serum IGF-I may be involved in the progression of dementia in the oldest of the old [104]. An age-associated decline in serum IGF-I levels exist even in extremely old age, without being associated with lower body mass index, hypoalbuminemia, or poor functional status.

Less than $5 \%$ of the healthy men 20 to 40 years old have plasma IGF-I values of less than $350 \mathrm{U} \mathrm{l}^{-1}$, but the values are below this figure in $30 \%$ of the healthy men more than 60 [92]. Likewise, the nocturnal pulses of GH secretion become smaller or disappear with advanced age. If the plasma concentration of IGF-I falls below $350 \mathrm{U} \mathrm{l}^{-1}$ in older adults, no spontaneous circulating pulses of GH can be detected by currently available radioimmunoassay methods [92]. The concomitant decline in plasma concentrations of both hormones supports the view that the decrease in IGF-I results from diminished GH secretion $[26,92]$. Second, diminished secretion of GH is accompanied not only by a fall in the plasma IGF-I concentration but also by atrophy of the lean body mass and expansion of the mass of adipose tissue [93]. It may not be relevant to use the serum IGF-I level as an indicator of GH release in centenarians, but instead, the IGF-I level appeared to reflect its short-term nutritional status as a rapid turnover protein. Further longitudinal studies, including assessment of IGFBPs and the association of IGF-I with dementia, should be conducted in the future.

Physiological age-related muscle loss and weakness is referred to as sarcopenia. The etiology is multifactorial and not fully understood. However, during aging, there is evidence of declining activity of the GH-IGF-I axis, which is mainly dependent on age-related variations in the hypothalamic control of somatotroph function (somatopause). It has been reported that in older individuals, there is reduced GH production and attenuated IGF-I response to high-resistance exercise [39]. Furthermore, previous studies have demonstrated a delayed response to FGF-2 with aging satellite cells, most probably because of delayed expression of FGF-2 receptors and delayed binding of FGF-2 to the receptors [9].

The results of cross-sectional studies suggest that sarcopenia is a major determinant of aging-associated 
decrements in strength [31, 84]. Sarcopenia involves significant alterations in the architecture of human muscles that stem from a loss of some myofibers and the remodeling of those that remain [77, 101]. It has been suggested that sarcopenia results from both a loss of myofibers and a decrease in type II fiber size [65]. In humans, age-related myofiber loss and myofiber atrophy generally involve type IIa and IIb fibers, with a greater impact seen in the IIb fibers $[65,76]$.

From results of epidemiological studies and interventional trials using recombinant human GH, serum IGF-I levels have shown a positive association with muscle strength, lean body mass [95, 96], and physical activity [62], and they have shown a negative correlation with body mass index and the body fat index [81, 93]. However, in the elderly population, serum IGF-I levels have been reported to have no association with body mass index, body fat, or lean body mass, but they have been significantly correlated with nutritional parameters and liver function [41]. Moreover, recent epidemiologic studies demonstrated that low serum IGF-I levels may be associated with increased cardiovascular risk [48] and cognitive impairment [3] in the elderly population. These data suggest that IGF-I values in elderly persons may not represent their $\mathrm{GH}$ activities and determinants of serum IGF-I levels may differ from middleaged individuals.

IGF-I response to either acute or chronic physical activity remains unclear [59]. Based on several studies done in healthy young adults, there is an increase in circulating IGF-I in response to different types of exercise, either aerobic, resistance, or heavy ergometer cycling [10, $54,58,91]$, while exercise training improves local IGF-I expression without significant changes of systemic parameters of the GH-IGF-I axis. These findings indicate that exercise training has the therapeutic potential to attenuate peripheral skeletal muscle alterations in particular with respect to local IGF-I expression in patients with moderate cardiac heart failure [38].

Growing evidence suggest that IGF-I and FGF-2 play an important role in exercise-induced muscle hypertrophy and angiogenesis. Importantly, recent work suggests the possible synergism of local FGF-2 and circulating IGF-I in the regulation of the anabolic adaptation of muscles to exercise [103]. The mechanisms that mediate the functional adaptation of the skeletal muscle appear to reside, primarily, within the impacted muscle. This circumstance accounts for the specific adaptation of effected muscles. The skeletal muscle loading experienced as part of occupational and athletic activities often includes periods of loaded muscle shortening and lengthening as well as periods during which muscles are activated but no external length changes occur (isometric loading). The relative contribution of these three modes of loading to the processes that stimulate muscle adaptation is of great interest in the area of programmed resistance training. It is well known that resistance training paradigms that include sufficient intensity, frequency, and duration can induce skeletal muscle adaptations that include compensatory hypertrophy [57]. It has also become common for such programs to emphasize one particular training mode (e.g., lengthening, shortening, or isometric). Training programs that have employed relatively pure shortening, lengthening, or isometric loading have demonstrated that each of these three modes of loading can stimulate muscle adaptations, including hypertrophy, and strength gains [19, $32,33,42,45,51,53,60,73,75,102,105]$.

Muscle mass is arguably the most important determinant of functional capabilities and as such is an important consideration in a number of occupational and clinical settings. Load-bearing or resistance-type exercise is the primary method for the maintenance of, increase in, or recovery of muscle mass. This can be particularly important in settings where muscle atrophy is a risk such as bed rest or spaceflight [47]. It is well established that exercise is a significant determinant of muscle mass and function.

As mentioned previously, the GH-IGF-I axis and FGF-2 are important physiological regulators of fetal and postnatal growth and development [48]. Physical exercise has a significant impact on the GH-IGF-I axis. However, data from studies evaluating IGF-I response to exercise are controversial. Findings indicate that although both peak aerobic capacity and circulating IGF-I levels decline with age, aerobic capacity is not independently related to circulating IGF-I in healthy men and women across the adult lifespan [43].

Decline in muscle strength and muscle mass with age is well documented [50, 51] and is associated with a deterioration of health status and functional abilities [5, 47]. Strength training is thought to be an effective intervention against sarcopenia because it increases muscle strength and muscle mass in the elderly [22, 23, 29, 37, 46, 98]. Muscle mass and neuromuscular factors contribute to losses in strength with age $[52,63]$ and gains in strength with strength training [34, 37].

While some studies have demonstrated no change in circulating IGF-I levels, in many others, exercise induced a transient increase in IGF-I levels resulting from acute release of IGF-I from its binding proteins [59]. Furthermore, IGF-I response depends on exercise type, intensity, and duration as well as training status [88, 90]. However, Bermon et al. [8] investigated the effects of an acute bout of exercise on total and free IGF-I and IGFBP-3 plasma concentrations, 32 healthy elderly subjects (67-80 years, 16 men) performed a strength test. Subjects were then randomly assigned to habitual physical activity or to an 8-week strength-training program. After 8 weeks, both sedentary and trained groups underwent blood samplings 
under the abovementioned conditions. The exercising group showed increased total and free IGF-I concentrations immediately $(+17.7$ and $+93.8 \%$, respectively) and $6 \mathrm{~h}$ $(+7.5$ and $+31.2 \%$, respectively) after the test, whereas no significant changes in IGFBP-3 concentrations were observed in either exercising or resting control groups. Strength training induced no significant changes in baseline IGF-I and IGFBP-3 concentrations. Trained and sedentary groups showed a similar hormonal response pattern to the strength test, which consisted of increased total and free IGF-I concentrations, indicating that strength exercise can induce an early and sustained IGF-I release, in elderly subjects, regardless of their training status. Resistance exercise is known to dramatically increase protein synthesis, accretion, and muscle hypertrophy $[2,21]$. Whereas Adams et al. $[2,28]$ reported that muscle IGF-I is elevated early in the time course of myogenesis in overloaded skeletal muscle, the precise role that IGF-I plays in mediating this process (systemic vs local) is still poorly defined [21].

There are not many studies on IGF-I response to exercise in older age during which the activity of the GH-IGF-I axes declines. Specifically, the response of older individuals to acute all-out anaerobic exercise has not yet been investigated. In the few studies conducted to date in older individuals, controversial results have been obtained [36, 85, 97]. Most studies dealing with the acute response of IGF-I to resistance exercise have shown no change in serum IGF-I level $[11,55]$. The chronic adaptation of circulating IGF-I in response to resistive training is controversial as well. While a few studies have reported no change in resting levels of IGF-I after short-term resistance training [40, 56, 99], other studies have shown elevations in IGF-I during short/long-term resistance-training programs [88, 91], particularly during high-volume training $[61,72]$. Furthermore, IGF-I increased after endurance type physical training [94] and triathlon training [70]. The mechanism of this response has not been fully resolved and likely involves both increased skeletal muscle IGF-I release and increased clearance rate of IGF-I from IGFBP [59].

Anaerobic power is characterized by exposing subjects to a very high degree of sudden strenuous all-out exercise. Little data are available on changes in the levels of IGF-I and FGF-2 after sudden strenuous anaerobic exercise in healthy older subjects. Furthermore, the effect of fitness level on these responses has not been studied yet. It has been hypothesized [4] that aerobically trained older men would manifest greater alterations in serum IGF-I and FGF-2 levels after the Wingate anaerobic test, than the untrained men.

When evaluating the effect of fitness level on IGF-I and FGF-2 responses after all-out anaerobic exercise in healthy older men, suggested fitness level dependent alterations in the response of older individuals to the Wingate anaerobic exercise regarding the levels of IGF-I and FGF-2. The study demonstrates that trained compared to untrained older men had lower pre-exercise serum levels of IGF-I and higher pre-exercise FGF-2 levels. After the Wingate anaerobic exercise, there was a transient elevation in the level of IGF-I in both higher-fit and lower-fit individuals. However, IGF-I elevation was significant only in the trained individuals. Contrary to IGF-I, postexercise levels of FGF-2 decreased dramatically to almost undetectable levels in both groups and remained low for 50 min into recovery. The data of the study of Amir et al. [4] suggest that during aging, fitness level is an important determinant of growth factors responses to exercise.

By modulating the anabolic effects of growth factors, the fitness level may have positive effects on aging-associated skeletal muscle loss. This suggests that despite a decline in the GH-IGF-I axis in older age, IGF-I response to acute exercise improves among better-trained subjects. The exercise-induced anabolic adaptations of skeletal muscle are mostly attributed to IGF-I. Given that IGF-I regulation is involved in aging-associated sarcopenia and that anaerobic muscle activity is represented in many daily life activities of the elderly, these results highlight the clinical significance of IGF-I regulation during aging and further support the notion that exercise training especially for older individuals can be beneficial.

Surprisingly, Amir et al. [4] have suggested that at rest, circulating IGF-I in the trained were lower by $17 \%$ compared to the untrained older individuals. The discrepancy between higher levels of IGF-I in healthy young after 2 weeks of strenuous aerobic training [94] and this data showing lower levels of IGF-I in trained compared to untrained older individuals might be explained by the finding of higher IGFBP-1 levels in older age [7]. Unlike IGF-I response, pre-exercise FGF-2 was $14 \%$ higher in the trained compared to the untrained older individuals and decreased dramatically $(75 \%$ reduction in the trained group and $93 \%$ reduction in the untrained group), in response to the all-out anaerobic exercise, remaining low for at least $50 \mathrm{~min}$ into recovery. Similar results have been obtained by Elyakim et al. [20,78], who found a significant reduction in circulating FGF-2 in healthy young individuals after a single-wrist flexion exercise. Elyakim et al. [20] hypothesized that exercise promotes a marked reduction in circulating FGF-2 by inducing increased binding of FGF2 to endothelial and muscle cells receptors resulting in redistribution and local capture. However, the effect of exercise training was evaluated in none of these studies. Previous studies employing either knee-extensor ergometer training or intense intermittent endurance training have analyzed the adaptation of human skeletal muscle to exercise training at the transcriptional level. Because there was a slight or no change in the level of skeletal muscle 
FGF-2 messenger ribonucleic acid [49], increased synthesis does not seem to be the mechanism responsible for the elevation in pre-exercise circulating FGF-2. However, in vitro studies on differentiated human skeletal muscle cultures have demonstrated that mechanical load induces sarcoplasmic wounding and FGF-2 release from myofibers with a linear correlation between the degree of mechanical load and the amount of myofiber wounding and FGF-2 release $[12,13]$. In light of these results, it is possible that prolonged resistive training imitates mechanical load by causing myofiber damage and FGF-2 release into circulation. The resulting increase in circulating FGF-2 might be an important compensatory mechanism during aging, in which the anabolic effects of FGF-2 are reduced by decreased binding affinity and by the delayed expression of local FGF-2 receptors [9].

It may be speculated that the changes in IGF-I and FGF-2 may have positive anabolic effects on the induction of muscle and capillary growth, resulting in muscle hypertrophy and angiogenesis. Thus, the fitness-induced alteration in IGF-I and FGF-2 levels may counteract the process of skeletal muscle loss, by modulating their positive anabolic effects, on skeletal muscle. This may have clinical implications during aging in which the declined activity of growth factors is a major determinant of the loss of muscle strength and function. Therefore, during aging, the fitness level can alter circulating levels of IGF-I and FGF- 2 and can affect the response of both mediators to all-out anaerobic, resistive, and aerobic exercises. Future studies to elucidate the mechanisms behind these changes are desirable.

\section{Conclusions}

Exercise induce increases in IGF-I, IGF-I receptors, and IGF-I-activated signaling pathways. Although there is evidence that the aging muscle retains the ability to synthesize IGF-I, there is also evidence that aging may be associated with attenuation of the ability of exercise to induce an isoform of IGF-I that promotes satellite cell proliferation. Moreover, the aging muscle may be resistant to IGF-I, an effect that is reversed by exercise. However, it is clear that the overexpression of IGF-I in the muscle can protect against age-related sarcopenia [1]. Strength training appears to be the intervention of choice for the prevention and treatment of sarcopenia, based on efficacy and safety concerns with other interventions [6, 35]. IGF-I has been implicated in the loss of muscle with age [35], and IGF-I expression levels change as a consequence of strength training in older adults [24]. The literature has shown that in older adults, carriers of the 192 allele at the IGF1 locus have greater strength gains than noncarriers with strength training. However, it seems that advancing age, rather than declining serum levels of IGF-I, appears to be a major determinant of life-time changes in body composition in women and men [80].

\section{References}

1. Adamo ML, Farrar RP (2006) Resistance training, and IGF involvement in the maintenance of muscle mass during the aging process. Ageing Res Rev 5:310-331

2. Adams GR, Haddad F, Baldwin KM (1999) Time course of changes in markers of myogenesis in overloaded rat skeletal muscles. J Appl Physiol 87:1705-1712

3. Aleman A, Verhaar HJ, Haan EH et al (1999) Insulin-like growth factor-I and cognitive function in healthy older men. $\mathrm{J}$ Clin Endocrinol Metab 84:471-475

4. Amir R, Ben-Sira D, Sagiv M (2007) IGF-I and FGF-2 responses to Wingate Anaerobic Test in older men. J Sports Sci Med 6:227-232

5. Aniansson A, Zetterberg C, Hadberg M, Henriksson K (1984) Impaired muscle function with aging. A background factor in the incidence of fractures of the proximal end of the femur. Clin Orthop 191:193-200

6. Bamman MM, Hill VJ, Adams GR et al (2003) Gender differences in resistance-training-induced myofiber hypertrophy among older adults. J Gerontol Ser A Biol Sci Med Sci 58:108116

7. Benbassat CA, Maki KV, Unterman TG (1997) Circulating levels of insulin-like growth factor (IGF) binding proteins 1 and 3 in aging men: relationships to insulin, glucose, IGF, and dehydroepiandrosterone sulfate levels and anthropometric measures. J Clin Endocrinol Metab 82:1484-1491

8. Bernard P, Altare S, Dolisi C (1999) Responses of total and free insulin-like growth factor-I and insulin-like growth factor binding protein- 3 after resistance exercise and training in elderly subjects. Acta Physiol Scand 165:51-56

9. Brickman YG, Ford MD, Small DH, Nurcombe V (1995) Heparan sulphates mediate the binding of basic fibroblast growth factor to a specific receptor on neural precursor cells. J Biol Chem 270:24941-24948

10. Cappon J, Brasel JA, Mohan S, Cooper DM (1994) Effect of brief exercise on circulating insulin-like growth factor-I. J Appl Physiol 76:2490-2496

11. Chandler R, Byrne HK, Patterson JG, Ivy JL (1994) Dietary supplements affect the anabolic hormones after weight-training exercise. J Appl Physiol 76:839-845

12. Clarke MSF, Khakee R, McNeil PL (1993) Loss of cytoplasmic basic fibroblast growth factor from physiologically wounded myofibers of normal dystrophic muscle. J Cell Sci 106:121-133

13. Clarke MSF, Feeback DL (1996) Mechanical load induces sarcoplasmic wounding and FGF release in differentiated human skeletal muscle cultures. FASEB J 10:502-509

14. Clemmons DR, Wyk JJ (1984) Factors controlling blood concentration of somatomedin C. Clin Endocrinol Metab 13:113-143

15. Corpas E, Harman SM, Blackman MR (1993) Human growth hormone and human aging. Endocr Rev 14:20-39

16. D'Costa AP, Ingram RL, Lenham JE, Sonntag WE (1993) The regulations and mechanisms of actions of growth hormone and insulin-like growth factor 1 during normal ageing. J Reprod Fertil Suppl 46:87-98

17. Delbono O, O'Rourke KS, Ettinger WH (1995) Excitationcalcium release uncoupling in aged single human skeletal muscle fibers. J Membr Biol 148:211-222 
18. Delbono O, Renganathan M, Messi ML (1997) Regulation of mouse skeletal muscle L-type $\mathrm{Ca} 2+$ channel by activation of the insulin-like growth factor-1 receptor. J Neurosci 17:6918-6928

19. Dudley GA, Tesch PA, Miller BJ, Buchanan P (1991) Importance of eccentric actions in performance adaptations to resistance training. Aviat Space Environ Med 62:543-550

20. Eliakim A, Youngman OH, Cooper DM (2000) Effect of single wrist exercise on fibroblast growth factor-2, insulin-like growth factor and growth hormone. Am J Physiol Regul Integr Comp Physiol 279:R548-R553

21. Farrell PA, Fedele MJ, Vary TC, Kimball SR, Lang CH, Jefferson LS (1999) Regulation of protein synthesis after resistance exercise in diabetic rats. Am J Physiol Endocrinol Metab 276:E721-E727

22. Fiatarone MA, Marks EC, Ryan ND, Meredith CM, Lipsitz LA, Evans WJ (1990) High-intensity strength training in nonagenarians. JAMA 263:3029-3034

23. Fiatarone MA, O’Neill EF, Ryan ND et al (1994) Exercise training and nutritional supplementation for physical frailty in very elderly people. N Engl J Med 330:1769-1775

24. Fiatarone Singh MA, Ding W, Manfredi TJ et al (1999) Insulin-like growth factor I in skeletal muscle after weightlifting exercise in frail elders. Am J Physiol Endocrinol Metab 277:E135-E143

25. Finkelstein JW, Boyar RM, Roffwarg HP, Kream J, Hellman L (1972) Age-related change in the twenty-four-hour spontaneous secretion of growth hormone. J Clin Endocrinol Metab 35:665-670

26. Florini JR, Prinz PN, Vitiello MV, Hintz RL (1985) Somatomedin$\mathrm{C}$ levels in healthy young and old men: relationship to peak and 24-hour integrated levels of growth hormone. J Gerontol 40:2-7

27. Florini JR, Ewton DZ, Magri KA, Mangiacapra FJ (1993) Adv Exp Med Biol 343:319-326

28. Florini JR, Ewton DZ, Coolican SA (1996) Growth hormone and the insulin-like growth factor system in myogenesis. Endocr Rev 17:481-517

29. Frontera WR, Meredith CN, O’Reilly KP, Knuttgen HG, Evans WJ (1988) Strength conditioning in older men: skeletal muscle hypertrophy and improved function. J Appl Physiol 64:1038-1044

30. Frontera WR, Hughes VA, Lutz KJ, Evans WJ (1991) A crosssectional study of muscle strength and mass in 45-to 78-yr-old men and women. J Appl Physiol 71:644-650

31. Frontera WR, Suh D, Krivickas LS, Hughes VA, Goldstein R, Roubenoff R (2000) Skeletal muscle fiber quality in older men and women. Am J Physiol Cell Physiol 279:C611-C618

32. Garfinkel S, Cafarelli E (1992) Relative changes in maximal force, EMG, and muscle cross-sectional area after isometric training. Med Sci Sports Exerc 24:1220-1227

33. Adams GR, Cheng DC, Haddad F, Baldwin KM (2004) Skeletal muscle hypertrophy in response to isometric, lengthening, and shortening training bouts of equivalent duration. J Appl Physiol 96:1613-1618

34. Grimby G, Aniansson A, Hedberg M, Henning GB, Grangard V, Kvist H (1992) Training can improve muscle strength and endurance in 78-to 84-yr-old men. J Appl Physiol 73:2517-2523

35. Grounds MD (2002) Reasons for the degeneration of ageing skeletal muscle: a central role for IGF-1 signaling. Biogerontology 3:19-24

36. Hagberg JM, Seals DR, Young JE et al (1988) Metabolic responses to exercise in young and older athletes and sedentary men. J Appl Physiol 65:900-908

37. Häkkinen K, Häkkinen A (1995) Neuromuscular adaptations during intensive strength training in middle-aged and elderly males and females. Electromyogr Clin Neurophysiol 35:137-147

38. Hambrecht R, Schulze PC, Gielen S et al (2005) Effects of exercise training on insulin-like growth factor-I expression in the skeletal muscle of non-cacectic patients with chronic heart failure. Eur J Cardiovasc Prev Rehabil 12:401-406
39. Hameed M, Orrell RW, Cobbold M, Goldspink G, Harridge SDR (2003) Expression of IGF-I splice variants in young and old human skeletal muscle after high resistance exercise. J Physiol 547:247-254

40. Hansen S, Kvorning T, Kjaer M, Sjogaard G (2001) The effect of short-term strength training on human skeletal muscle: the importance of physiologically elevated hormone levels. Scand J Med Sci Sports 11:347-354

41. Harris TB, Douglas K, Roubenoff R et al (1997) Association of insulin-like growth factor-I with body composition, weight history, and past health behaviors in the very old: the Framingham Heart Study. J Am Geriatr Soc 45:133-139

42. Hather BM, Tesch PA, Buchanan P, Dudley GA (1991) Influence of eccentric actions on skeletal muscle adaptations to resistance training. Acta Physiol Scand 143:177-185

43. Haydar ZR, Blackman MR, Tobin JD, Wright JG, Fleg JL (2000) The relationship between aerobic exercise capacity and circulating IGF-1 levels in healthy men and women. J Am Geriatr Soc 48:139-145

44. Hochberg MC, Lethbridge-Cejku M, Scott WW Jr, Reichle R, Plato CC, Tobin JD (1994) Serum levels of insulin-like growth factor in subjects with osteoarthritis of the knee. Data from the Baltimore Longitudinal Study of Aging. Arthritis Rheum 37:1177-1180

45. Housh TJ, Housh DJ, Weir JP, Weir LL (1995) Effects of eccentriconly resistance training and detraining. Int J Sports Med 17:145-148

46. Hurley BF, Redmond RA, Pratley RE, Treuth MS, Rogers MA, Goldberg AP (1995) Effects of strength training on muscle hypertrophy and muscle cell disruption in older men. Int J Sports Med 16:378-384

47. Hyatt RH, Whitelaw MN, Bhat A, Scott S, Maxwell JD (1990) Association of muscle strength with functional status of elderly people. Age Ageing 19:330-336

48. Janssen JAMJL, Stolk RP, Pols HAP, Grobbee DE, Lamberts SWJ (1998) Serum total IGF-I, free IGF-I, and IGFBP-1 levels in an elderly population: relation to cardiovascular risk factors and disease. Arterioscler Thromb Vasc Biol 18:277-282

49. Jensen L, Bangsbo J, Hellsten Y (2004) Effect of high intensity training on capillarization and presence of angiogenic factors in human skeletal muscle. J Physiol 557:571-582

50. Jones AJS, O'Connor JV (1982) Chemical characterization of methionyl human growth hormone. In: Hormone drugs: proceedings of the FDA-USP Workshop on Drug and Reference Standards for Insulin, Somatropins, and Thyroid-axis Hormones, Bethesda, MD, May 19-21, 1982. US Pharmacopeial Convention, Rockville, MD, pp 335-351

51. Jones DA, Rutherford OM (1987) Human muscle strength training: the effects of three different regimes and the nature of the resultant changes. J Physiol 391:1-11

52. Kallman DA, Plato CC, Tobin JD (1990) The role of muscle loss in the age-related decline of grip strength: cross-sectional and longitudinal perspectives. J Gerontol 45:M82-M88

53. Kanehisa H, Nagareda H, Kawakami Y et al (2002) Effects of equivolume isometric training programs comprising medium or high resistance on muscle size and strength. Eur J Appl Physiol $87: 112-119$

54. Kraemer WJ, Gordon SE, Fleck SJ et al (1991) Endogenous anabolic hormonal and growth factor responses to heavy resistance exercise in males and females. Int J Sports Med 12:228-235

55. Kraemer WJ, Aguilera BA, Terada M et al (1995) Responses of IGF-I to endogenous increases in growth hormone after heavyresistance exercise. J Appl Physiol 79:1310-1315

56. Kraemer WJ, Hakkinen K, Newton RU et al (1997) Effects of heavy-resistance training on hormonal response patterns in younger vs. older men. J Appl Physiol 87:982-992

57. Kraemer WJ, Adams K, Cafarelli E et al (2002) American College of Sports Medicine position stand. Progression models in resistance training for healthy adults. Med Sci Sports Exerc 34:364-380 
58. Kraemer RR, Durand RJ, Acevedo EO (2004) Rigorous running increases growth hormone and insulin-like growth factor-I without altering ghrelin. Exp Biol Med 229:240-246

59. Kraemer WJ, Ratamess NA (2005) Hormonal responses and adaptations to resistance exercise and training. Sports Med 35:339-361

60. Komi PV, Buskirk ER (1972) Effect of eccentric and concentric muscle conditioning on tension and electrical activity in human muscle. Ergonomics 15:417-434

61. Koziris LP, Hickson RC, Chatterton RT Jr et al (1999) Serum levels of total and free IGF-I and IGFBP-3 are increased and maintained in long-term training. J Appl Physiol 86:14361442

62. Landin-Wilhelmsen K, Wilhelmsen L, Lappas G et al (1994) Serum insulin-like growth factor-I in a random population sample of men and women: relation to age, sex, smoking habits, coffee consumption and physical activity, blood pressure and concentrations of plasma lipids, fibrinogen, parathyroid hormone and osteocalcine. Clinical Endocrinol 41:351-357

63. Larsson L, Grimby G, Karlsson J (1979) Muscle strength and speed of movement in relation to age and muscle morphology. $\mathrm{J}$ Appl Physiol 46:451-456

64. LeRoith D (1991) Insulin-like growth factors: molecular and cellular aspects. CRC, Boca Raton, FL, pp 1-54

65. Lexell J, Downham D (1992) What is the effect of ageing on type 2 muscle fibres? J Neurol Sci 107:250-251

66. Lindle R, Metter E, Lynch N et al (1997) Age and gender comparisons of muscle strength in 654 women and me aged 2093. J Appl Physiol 83:1581-1587

67. Lord SR, Ward JA, Williams P, Anstey K (1994) Physiological factors associated with falls in older community-dwelling women. J Am Geriatr Soc 42:1110-1117

68. Lynch NA, Metter EJ, Lindle RS et al (1999) Muscle quality I: age-associated differences in arm vs. leg muscle groups. J Appl Physiol 86:188-194

69. Lynch CD, Lyons D, Khan A, Bennett SA, Sonntag WE (2001) Insulin-like growth factor-1 selectively increases glucose utilization in brains of aged animals. Endocrinology 142:506-509

70. Maimoun L, Galy O, Manetta J et al (2004) Competitive season of triathlon does not alter bone metabolism and bone mineral status in male triathletes. Int J Sports Med 25:230-234

71. Markowska AL, Mooney M, Sonntag WE (1998) Insulin-like growth factor-1 ameliorates age-related behavioral deficits. Neuroscience 87:559-569

72. Marx JO, Ratamess NA, Nindl BC et al (2001) Low-volume circuit versus high-volume periodized resistance training in women. Med Sci Sports Exerc 33:635-643

73. Mayhew TP, Rothstein JM, Finucane SD, Lamb RL (1995) Muscular adaptation to concentric and eccentric exercise at equal power levels. Med Sci Sports Exerc 27:868-873

74. Meites J (1988) Neuroendocrine biomarkers of aging in the rat. Exp Gerontol 23:349-358

75. Morissey MC, Harman EA, Johnson MJ (1995) Resistance training modes: specificity and effectiveness. Med Sci Sports Exerc 27:648-660

76. Moulias R, Meaume S, Raynaud-Simon A (1999) Sarcopenia, hypermetabolism, and aging. Z Gerontol Geriatr 32:425-432

77. Narici MV, Maganaris CN, Reeves ND, Capodaglio P (2003) Effect of aging on human muscle architecture. J Appl Physiol 95:2229-2234

78. Nemet D, Hong S, Mills PJ, Ziegler G, Hill M, Cooper M (2002) Systemic vs. local cytokine and leukocyte responses to unilateral wrist flexion exercise. J Appl Physiol 93:546-554

79. Nilsson A, Isgaard J, Lingahl A et al (1986) Regulation by growth hormone of number of chondrocyte containing IGF-1 in rat growth plate. Science 233:571-574
80. O'Connor KG, Tobin JD, Harman SM et al (1998) Serum levels of insulin-like growth factor-I are related to age and not to body composition in healthy women and men. J Gerontol Ser A Biol Sci Med Sci 53:M176-M182

81. Papadakis MA, Grady D, Tierney MJ, Black D, Wells L, Grunfeld C (1995) Insulin-like growth factor-I and functional status in healthy older men. J Am Geriatr Soc 43:1350-1355

82. Rantanen T, Era P, Heikkinen E (1997) Physical activity and the changes in maximal isometric strength in men and women from the age of 75 to 80 years. J Am Geriatr Soc 45:1439-1445

83. Rantanen T, Guralnik JM, Sakari-Rantala R et al (1999) Disability, physical activity, and muscle strength in older women: the women's health and aging study. Arch Phys Med Rehabil 80:130-135

84. Rantanen T (2003) Muscle strength, disability and mortality. Scand J Med Sci Sports 13:3-8

85. Ravaglia G, Forti P, Maioli F et al (2001) Regular moderate intensity physical activity and blood concentrations of endogenous anabolic hormones and thyroid hormones in aging men. Mech Ageing Dev 122:191-203

86. Reed R, Pearlmutter L, Yochum K, Meredith K, Mooradian A (1991) The relationship between muscle mass and muscle strength in the elderly. J Am Geriatr Soc 39:555-561

87. Renganathan M, Sonntag WE, Delbono O (1997) Biochem Biophys Res Commun 235:784-789

88. Roelen CA, de Vries WR, Koppeschaar HP, Vervoorn C, Thijssen JH, Blankenstein MA (1997) Plasma insulin-like growth factor-I and high affinity growth hormone-binding protein levels increase after two weeks of strenuous physical training. Int J Sports Med 18(4):238-241

89. Rommel C, Bodine SC, Clarke A et al (2001) Mediation of IGFI- induced skeletal myotube hypertrophy by $\mathrm{PI}(3) \mathrm{K} / \mathrm{Akt} / \mathrm{mTOR}$ and PI(3)K/Akt/GSK3 pathways. Nat Cell Biol 3:1009-1013

90. Rosendal L, Langberg H, Flyvbjerg A, Frystyk J, Ørskov H, Kjaer M (2002) Physical capacity influences the response of insulin-like growth factor and its binding proteins to training. J Appl Physiol 93:1669-1675

91. Rubin MR, Kraemer WJ, Maresh CM et al (2005) High-affinity growth hormone binding protein and acute heavy resistance exercise. Med Sci Sports Exerc 37:395-403

92. Rudman D, Kutner MH, Rogers CM, Lubin MF, Fleming GA, Bain RP (1981) Impaired growth hormone secretion in the adult population: relation to age and adiposity. J Clin Invest 67:1361-1369

93. Rudman D (1985) Growth hormone, body composition, and aging. J Am Geriatr Soc 33:800-807

94. Sinaki M, McPhee M, Hodgson S, Merritt J, Offord K (1994) Relationship between bone mineral density of spine and strength of back extensors in healthy postmenopausal women. Mayo Clin Proc 61:116-122 1986

95. Taaffe DR, Pruitt L, Hintz RL et al (1994) Effects of recombinant human growth hormone on the muscle strength response to resistance exercise in elderly men. J Clin Endocrinol Metab 79:1361-1366

96. Thompson JL, Butterfield GE, Marcus R et al (1995) The effects of recombinant human insulin-like growth factor and growth hormone on body composition in elderly women. J Clin Endocrinol Metab 80:1845-1852

97. Tissandier O, Péres G, Fiet J, Piette F (2001) Testosterone, dehydroepiandrosterone, insulin-like growth factor-I, and insulin in sedentary and physically trained aged men. Eur J Appl Physiol $85: 177-184$

98. Treuth MS, Ryan AS, Pratley RE et al (1994) Effects of strength training on total and regional body composition in older men. J Appl Physiol 77:614-620

99. Walker KS, Kambadur R, Sharma M, Smith KK (2004) Resistance training alters plasma myostatin but not IGF-I in healthy men. Med Sci Sports Exerc 36:787-793 
100. Welle S (1998) Growth hormone and IGF-I as anabolic agents. Curr Opin Clin Nutr Metab Care 1:257-262

101. Welle S (2002) Cellular and molecular basis of age-related sarcopenia. Can J Appl Physiol 27:19-41

102. Welsh L, Rutherford OM (1996) Effects of isometric strength training on quadriceps muscle properties in over 55 year olds. Eur J Appl Physiol 72:219-223

103. Wilkie RS, O’Neill IE, Butterwith SC, Duclos MJ, Goddard C (1995) Regulation of chick muscle satellite cells by fibroblast growth factors: interaction with insulin-like growth factor-I and heparin. Growth Regul 5:18-27

104. Arai Y, Hirose N, Yamamura K et al (2001) Serum insulin-like growth factor-1 in centenarians: implications of IGF-1 as a rapid turnover protein. J Gerontol Ser A Biol Sci Med Sci 56A:M79M82

105. Young A, Stokes M, Round JM, Edwards RHT (1983) The effect of high-resistance training on strength and cross-sectional area of the human quadriceps. Eur J Clin Invest 13:11-417 